\title{
Contribution of Entrepreneurship to the Social Integration of People Intellectual Disabilities: A Case Study Based on the Analysis of Social Networks
}

\author{
Virginia Barba-Sánchez ${ }^{1}$, Yolanda Salinero ${ }^{2 *}$, Pedro Jiménez-Estevez ${ }^{2}$ and \\ Esteban Galindo ${ }^{3}$
}

${ }^{1}$ Business Administration Department, ESII, Universidad de Castilla-La Mancha, Albacete, Spain, ${ }^{2}$ Business Administration Department, Faculty of Legal and Social Science, Universidad de Castilla-La Mancha, Toledo, Spain, ${ }^{3}$ CECAP, Ronda Buenavista, Toledo, Spain

OPEN ACCESS

Edited by:

Jose Carlos Sánchez-García, University of Salamanca, Spain

Reviewed by: Karla Olmo-Sánchez, Universidad Autónoma de Ciudad Juárez, Mexico Carmen De La Calle Maldonado, Universidad Francisco de Vitoria,

Spain

*Correspondence: Yolanda Salinero yolanda.salinero@uclm.es

Specialty section: This article was submitted to Organizational Psychology, a section of the journal

Frontiers in Psychology

Received: 14 June 2021 Accepted: 13 September 2021 Published: 12 October 2021

Citation:

Barba-Sánchez V, Salinero Y,

Jiménez-Estevez $P$ and Galindo E (2021) Contribution of Entrepreneurship to the Social Integration of People Intellectual Disabilities: A Case Study Based on the Analysis of Social Networks.

Front. Psychol. 12:725060. doi: 10.3389/fpsyg.2021.725060
In an environment characterized by high unemployment rates among people with disabilities, the objective of the present work is to analyze entrepreneurship as a labor option which fully inserts people with intellectual disabilities (PWID) into their societies. In order to carry out this research, a case study methodology based on social network analysis has been adopted, given the nature of the variables analyzed. The results indicate that the fact of having managed to start up the company has been an important source of self-confidence and inspiration, as well as increasing and intensifying the social networks of PwID involved in the entrepreneurial project.

Keywords: entrepreneurship, intellectual disabilities, social integration, social networks, case study

\section{INTRODUCTION}

In an environment characterized by high unemployment rates among people with disabilities $(\mathrm{PwD})$, this group's social incorporation is undermined by their economic dependence both on their families and on public institutions (ODISMET, 2018). According to data from the INE (2020), in 2019, the unemployment rate among PwD in Spain exceeded that of the non-disabled population by more than ten points (23.9\% compared to 17.1$)$, a gap that has consisted during the evolution of such data since records have been kept. Although the main objective of Law 13/1982 (Law on the Social Integration of the Disabled) has been to reduce this gap at a national level in order to achieve the full social integration of this group, we observe that, in fact, this has not been the case (Calderón-Milán et al., 2020); the relevance of this problem is underlined by the fact that, at the national level, almost two million people of working age (from 16 to 64 years of age) have some form of disability, either permanent or temporary, thereby representing $6.2 \%$ of the total working-age population (INE, 2018). At the level of the European Union (EU), this percentage is approximately $16 \%$, a percentage which is likely to increase as the population ages (Halabisky, 2014).

Manzanera-Román and Brändle (2019) point to employment as one of the most effective elements in the integration of people into society. Authors such as Bengisu and Balta (2011) 
suggest that the use of $\mathrm{PwD}$ would improve the quality of service and efficiency, reducing the employing company's costs. In practice, however, discrimination by employers plays a major part in PwD's low employment rates (Hashim and Wok, 2014; Beisland et al., 2016), while those who have been employed tend to be employed in low-skill and low-paid occupations (Meager and Higgins, 2011). In short, the problem is not only that PwDs have a high unemployment rate, but that those who do get a job often find it unsatisfactory (Darcy et al., 2020).

In this context, self-employment is a useful alternative (Dhar and Farzana, 2017; Barba-Sánchez et al., 2019), which contributes to PwD's social inclusion (Maritz and Laferriere, 2016) and which, even in a worst-case scenario, serves as a training program to improve employment (Doyel, 2002: Bruce and Schuetze, 2004). Furthermore, authors such as Pagán (2009) and Halabisky (2014) consider this alternative appropriate for $\mathrm{PwD}$ given that it can give them higher work flexibility in terms of workload and working hours, thereby allowing a better balance between their disability and their working life. Akinyemi (2016) points out that self-employment gives PwD the opportunity to be productive members of society, which, according to authors such as O'Neil et al. (2020) or Seelman (2008), increases their self-esteem and self-confidence. However, inclusive entrepreneurship defined by Maritz and Laferriere (2016, p. 46), as that which "contributes to social inclusion to give all people an equal opportunity to start and operate a business" in general, and more specifically inclusive entrepreneurship developed by $\mathrm{PwD}$ is a subject that is scarcely addressed both in specialized literature (Renko et al., 2015; Bagheri and Abbariki, 2017) and in public policies that promote it (Muñoz et al., 2019).

Among PwD, PwIDs are particularly vulnerable as they "tend to be largely sedentary and passive with negative implications for their self-confidence, constructive engagement time, environmental sensory input, and social status" (Lancioni et al., 2017 p. 282). However, previous literature on entrepreneurship among this group of PwID in the growing body of empirical research on entrepreneurs with disabilities (EwD) is almost non-existent (Hutchinson et al., 2021). This lack of knowledge presents policy makers and practitioners involved in the promotion and development of entrepreneurship among PwID with a challenge in developing effective strategies and programs (Bagheri and Abbariki, 2017). Hence, the objective of this work is to contribute to the study of entrepreneurship among PwID, specifically investigating the question: does entrepreneurship favor the social integration of PwID?

\section{ENTREPRENEURSHIP, SOCIAL NETWORKS THEORY AND SOCIAL INTEGRATION}

Keyes (1998 p. 122) defines social integration as "the evaluation of the quality of the relationships we maintain with society and the community." Following the Social and Cultural School of Thought (Dhar and Farzana, 2017), most of the time, entrepreneurship is undertaken when people feel supported by their social and cultural environment. From such thinking, the "Social-Inclusive" Model is born, which interprets the reality of PwID from the guarantee of fundamental rights. Thusly, it is assumed that it is the person themselves who should be the active participant in achieving their personal objectives, while the family, in turn, should serve as a support tool for achieving those objectives, maintaining an active role that facilitates access to the framework of fundamental rights; society, therefore, must be permeable, understanding PwID as another member of society, with all the rights and duties that pertain to such membership.

However, the disabilities not only affect individuals but also family groups, the local social environment and economy, society in general and its pertinent public authorities (OrtízGarcía and Olaz-Capitán, 2021), this type of inclusive entrepreneurship cannot be analyzed solely from the perspective of Stakeholder's Theory (Barba-Sánchez et al., 2021).

Social network theory allows the analysis of egocentric or personal networks, which are those centered on specific individuals and on which the studies of their behavior are focused, since they show the relationships of the context in which these individuals are immersed or anchored (Scott, 1991). Thus, social networks are a form of representation in which an attempt is made to identify the various social structures of human relationships (Barba-Sánchez and Molina-Ramírez, 2015). Lee et al. (2005) classify them as close primary networks, made up of members of the nuclear family, non-close primary networks, made up of friends, neighbors and work colleagues, and secondary networks, which include the rest of professional contacts.

Among the main conclusions of the Report on the Disability Entrepreneurship Ecosystem in Australia (Darcy et al., 2020), is the importance of social networking, not only for the success of the business project, but also for the personal development and social integration of PwIDs. The creation of the company favors the increase in the PwID's professional networks. Furthermore, having a larger network of contacts contributes both to job placement and mobility (Györi et al., 2019) and to alleviating and preventing social isolation (Thoresen et al., 2018). However, PwID often have much smaller social networks than people with other disabilities (van Asselt-Goverts et al., 2014).

Given that the aim of the present work was to analyze entrepreneurship as a labor option which fully inserts PwID into their societies, we intend to visualize the evolution of the entrepreneurial team's social networks, classifying them into personal networks, such as family and friends, and professional networks, such as customers, suppliers, and public institutions.

\section{METHODOLOGY}

In order to carry out this research, we have carried out a qualitative study that can be assimilated to a case study in which the information collected was done through in-depth interviews, which are a valid method for collecting information in numerous empirical and qualitative studies. However, due 
to the exploratory nature of this research and space limitations, we have only included the data in the graph that summarize the information collected. A social network analysis (SNA) has been adopted, given the nature of the variables analyzed. Case studies allow an analysis of the phenomenon under investigation within its real context, using multiple sources of evidence, both quantitative and qualitative (Villarreal and Landeta, 2010). In Yin's words (1989) when he speaks of the definition of a case study, he points out that they are empirical investigations which study a contemporary phenomenon within its real context, where the limit between the phenomenon and the context are not precisely shown, and in which multiple sources of evidence are used. For its part, SNA is based on social network theory, whose main axiom is "that a node's position in a network determines in part the opportunity and constraints that it encounters, and in this way plays an important role in a node's outcomes" (Borgatti et al., 2009 p. 894). In this sense, according to Rutte et al. (2010), SNA allows us to understand the spatial dimension of the social capital of individuals. Specifically, the current study's methodology consists of drawing the relational social networks of PwID before and after undertaking entrepreneurship (the so-called ego network), observing the differences between the two temporal moments.

This technique not only allows us to draw the existing relationship for each actor (vertexes) but also the intensity of the relationship between two actors (edge thickness) and the direction of that relationship (arcs). In our case, the intensity of the relationship has been measured on a five-point Likert scale where 1 was an unknown person; 2, a known person; 3 , a known person with a weak connection and sporadic interactions; 4, a known person with medium connection and frequent interactions; and 5, a known person with strong connection who is part of the entrepreneur's daily life.

Our current analysis focused on a case of inclusive and collective entrepreneurship carried out entirely by PwID: coffee fertilizer. This cooperative company arose as a result of the Entrepreneurship Course for PwID taught by the University of Castilla-La Mancha (UCLM) during the 2016/17 Academic Year, and under the supervision and support of the Social Business Factory (SBF), a business incubator and seedbed for creating, monitoring, and advising of socially inclusive companies. Created in 2018 by 14 partners, this cooperative depends on a circular economic model that elaborates ecological hummus (fertilizer) from the waste of coffee grounds using the Californiana red worm. After its creation, 8 more partners joined the project, bringing the current number of partners to 22 (see Table 1 with description of the 22 Cooperative members). Table 2 lists all the stakeholders with whom at least one of the members of this cooperative has a relationship before and/or after the creation of the company.

\section{RESULTS AND DISCUSSION}

\section{Overview of the Interview Results}

Upon analyzing the case study, we can summarize the following results:
First of all, participants' families had a high level of involvement in the early stages of the project, helping to establish the cooperative's infrastructure. There were many interactions between families, which extended to the relationships between the participants themselves. At some point, this interaction damaged the relationships between some families and strengthened trust between others. The relationship of the participants with their own families did not change due to the entrepreneurship process per se, although it is true that the context generated with the business project has facilitated the professional team's training efforts in this sense, working transversally with other areas of the entity. It would be complicated to establish the relational flows in this aspect or to try to measure its average.
"One of the cooperative members, as a result of working in the cooperative, went to live in a sheltered flat, his mother said that before this he would never have imagined that he would have had the self-confidence to take this step."

Relationship between equals. All entrepreneurial processes promote collaboration and teamwork and the technical counseling that participants received placed great importance on cultivating these aspects in order to produce a cohesive group. At the quantitative level, the evolution that participants had regarding interpersonal and group relations based on the identity of the entrepreneur/worker is interesting.

- Participants. Related to the previous point, it is important to underline how each participant evolved parallelly in terms of maturation, self-concept and self-knowledge. In this way, the relations toward their equals and toward themselves undergo constant translation with a positive tendency toward personal and interpersonal evolution. As in the case of the families, it would be complicated to establish relational flows in the aspect or to try to measure their mean.

With regard to the SNA, as can be observed in Figure 1, the main link between all future entrepreneurs, prior to the creation of the company, was CECAP. In addition, the relations between the entrepreneurial team's members (drawn in fuschia) were weak (among the fourteen initial promoters) and even, in some cases, non-existent (among the eight new members).

Once the company had been established, the generation of an ego network (Figure 2) is observed in a dense network among the members of the company (especially among the initial promoters of the company), which is represented by the fuschia area. Additionally, their relations with external stakeholders have multiplied (eight new stakeholders were added, represented by triangles) and intensified considerably (greater edge thickness), especially the relations with the professional guide, with the network of cafés that supplied the raw material and with the neighboring orchards that share part of the municipally owned campus where the company is located. 
TABLE 1 | Cooperative members detail of Abono Café.

\begin{tabular}{|c|c|c|c|c|c|}
\hline Cooperative member & Gender & Age & Type of disability & Degree of disability & Educational level \\
\hline CM1 & Female & 31 & Psychica & $65 \%$ & School Graduate \\
\hline $\mathrm{CM} 2$ & Female & 26 & Psychica & $41 \%$ & Secondary level education \\
\hline CM3 & Female & 31 & Psychica & $65 \%$ & Secondary level education \\
\hline CM4 & Female & 35 & Psychica & $65 \%$ & Secondary level education \\
\hline CM5 & Female & 33 & Psychica & $65 \%$ & Secondary level education \\
\hline CM6 & Female & 28 & Psychica & $65 \%$ & Secondary level education \\
\hline CM7 & Male & 41 & Psychica & $68 \%$ & School Graduate \\
\hline CM8 & Female & 22 & Psychica & $81 \%$ & Secondary level education \\
\hline CM9 & Female & 35 & Psychica & $65 \%$ & Primary School \\
\hline CM10 & Male & 33 & Psychica & $65 \%$ & Basic Professional Training \\
\hline CM11 & Hombre & 38 & Psychica & $65 \%$ & No schooling completed \\
\hline CM12 & Male & 47 & Psychica & $65 \%$ & No schooling completed \\
\hline CM13 & Female & 43 & Psychica & $65 \%$ & School Graduate \\
\hline CM14 & Hombre & 26 & Psychica & $70 \%$ & Secondary level education \\
\hline CM15 & Male & 27 & $\begin{array}{l}\text { Psychical, physical, } \\
\text { and sensory }\end{array}$ & $76 \%$ & Primary School \\
\hline CM16 & Female & 31 & Psychica & $65 \%$ & Primary School \\
\hline CM17 & Female & 31 & Psychica & $69 \%$ & School Graduate \\
\hline CM18 & Female & 25 & Psychica & $65 \%$ & School Graduate \\
\hline CM19 & Female & 29 & Psychica & $67 \%$ & $\begin{array}{l}\text { Initial Professional Qualification } \\
\text { Program }\end{array}$ \\
\hline CM2O & Male & 31 & Psychica & $65 \%$ & Primary School \\
\hline $\mathrm{CM} 21$ & Female & 26 & Psychica & $65 \%$ & Primary School \\
\hline CM22 & Male & 30 & Psychica & $65 \%$ & Primary School \\
\hline
\end{tabular}

TABLE 2 | Stakeholders participating in the study.

\begin{tabular}{|c|c|}
\hline Stakeholder ID & Description \\
\hline CoopMember\# & $\begin{array}{l}\text { Cooperative Member Number \#. It is necessary to distinguish the first fourteen from the following eight, who joined the project after its } \\
\text { creation. }\end{array}$ \\
\hline PresidentCoop & President of the Cooperative and member \#3. \\
\hline SecretaryCoop & Secretary of the Cooperative and member \#11. \\
\hline TreasureCoop & Treasurer of the Cooperative and member \#13. \\
\hline ProfessionalCounsellor & Professional Couch that accompanies participants during entrepreneurial process. \\
\hline CECAP & Staff of the social entity CECAP, a Training Service based in Toledo who collaborated with the project. \\
\hline SBF & Staff of the Social Business Factory group, support platform, and monitoring of the entrepreneurial process. \\
\hline UCLMteacher & Professors of the course Entrepreneurship and Specificity, articulated through the UCLM. \\
\hline EOlteacher & Professors of the entrepreneurship course organized by the School of Industrial Organization (EOI). \\
\hline EOlstaff & Management team of the entrepreneurship course organized by EOI. \\
\hline TownHall & Members of Toledo City Hall sympathizing with the project. \\
\hline JCCM & Members of Regional Government of Castilla-La Mancha sympathizing with the project. \\
\hline CigarralBusiness & $\begin{array}{l}\text { Management team of the Cigarral del Ángel Custodio. First business partner with whom an agreement was signed for the temporary } \\
\text { transfer of space; the EU committee was received at its facilities and came to visit the project. }\end{array}$ \\
\hline GrecoMuseumStaff & Management team of the Greco Museum. First client of the company. \\
\hline Children\&Families & $\begin{array}{l}\text { Children and family members attending the awareness-raising workshop organized by the Greco Museum to promote the } \\
\text { entrepreneurial project. }\end{array}$ \\
\hline Caixabank & Director of the Caixabank office where the company's account was made. \\
\hline CaixabankVolunteers & Team of Caixabank volunteers, who offered a financial economy workshop to the entrepreneurs. \\
\hline Neighbours & Group of gardening neighbors who manage an urban gardening project and share part of the premises where the company is located. \\
\hline CafeNetwork & Network of cafeterias that collaborate with the project. \\
\hline BioenergyBusinesses & Entrepreneurs of the bioenergy company with which negotiations are being established. \\
\hline
\end{tabular}

\section{CONCLUSION}

The results indicate that the fact of having managed to start up the company has been an important source of self-confidence, in line with what Tirado-Valencia et al. (2021) say as well as increasing and intensifying the social networks of PwID involved in the entrepreneurial project, in line with results obtained by previous literature (Conroy et al., 2010; Thoresen et al., 2018; Caldwell et al., 2020). However, the process has faced additional challenges, such as social reticence and having to overcome the limitations derived from disability, which are conclusions of interest for policy makers and other social agents involved in disability. 


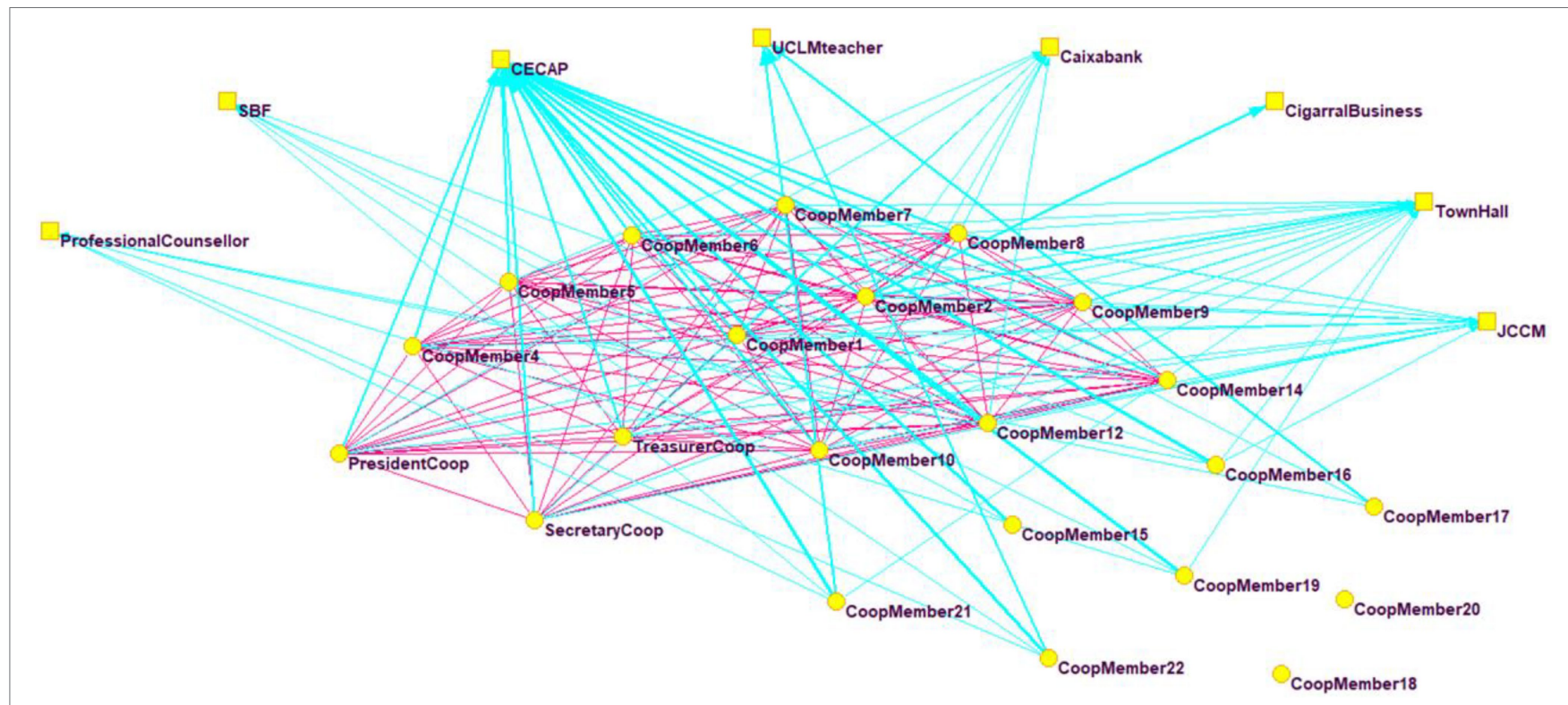

FIGURE 1 | Network of entrepreneurs before company creation. The members/workers of the cooperative (internal stakeholders) are represented by circles, and their relationships are displayed in fuschia, while external stakeholders (organizations that maintained some kind of contact prior to the creation of the company) are represented by squares, and their relationships are drawn in blue.

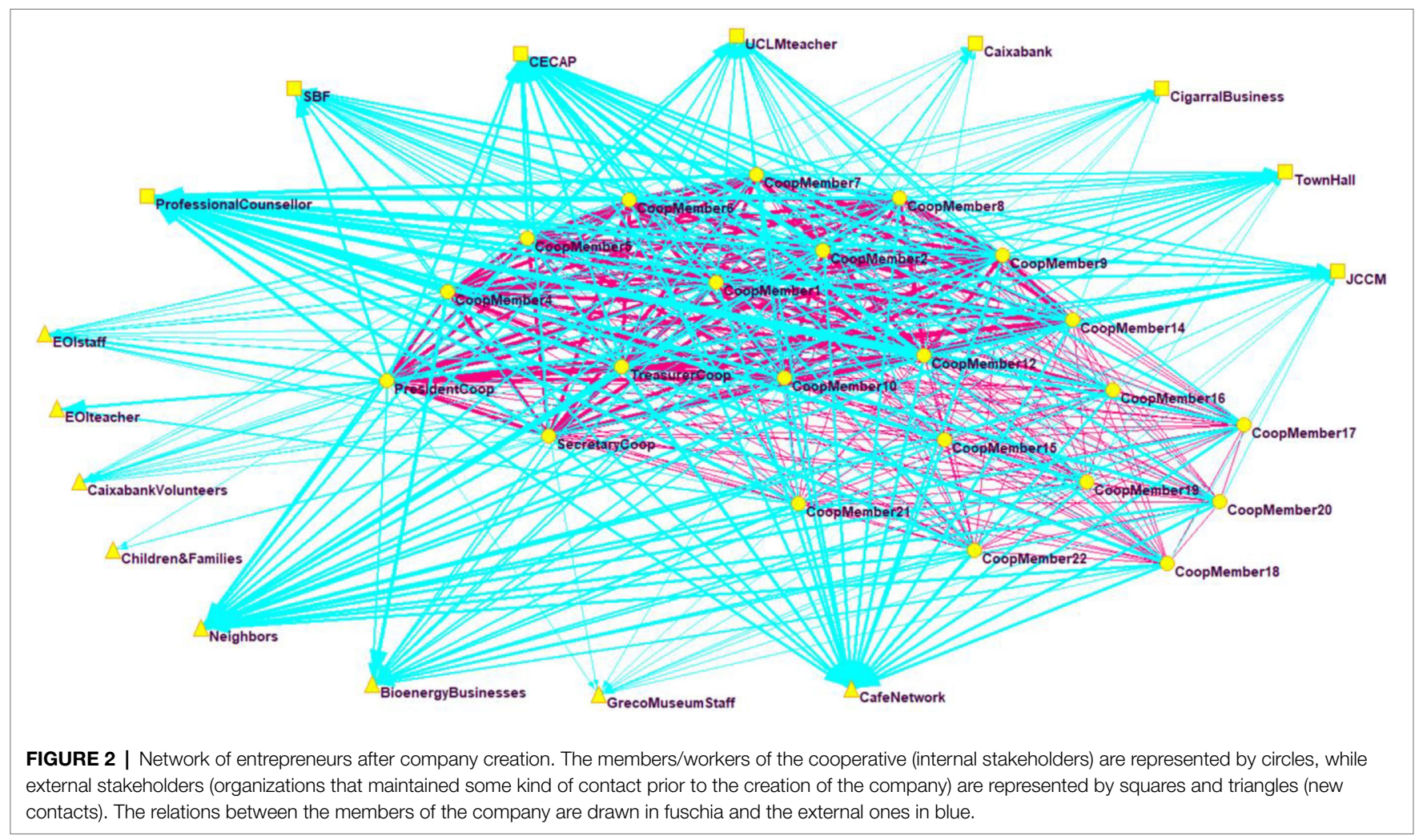

During the entire process of training, creating the company and carrying out the entrepreneurial activity, an essential and fundamental pillar has been the support and interest of the students' families: They are not mere spectators of the project, but also implicate themselves, helping students in some activities (a fact that strengthens family union even more, if possible). Additionally, it has been indispensable that the students have had the collaboration of a member of the social entity CECAP, 
who assigns each cooperative member the task that is most adequate for him/her and in which they can best develop their capacities.

One of the limitations of our study is that we have only collected evidence from one company, the first that has emerged from the inclusive entrepreneurship courses. It is foreseen that this line of work will continue at the University of Castilla-La Mancha (UCLM); in other words, we intend to continue giving courses and to continue supporting entrepreneurial ideas, with the hopes of expanding our sample with more companies created by PwID in the near future. As in Europe, the United States, and Australia (Larsson, 2020), there are no data on the number of Spanish companies owned by PwID (OrtízGarcía and Olaz-Capitán, 2021), so a relevant future work would be to quantify the group of entrepreneurs with intellectual disabilities (EwID).

Our work is eminently descriptive because what we are looking for is a study of the relationships between entrepreneurs and their networks. As future lines of inquiry, we will analyze, following the evidence pointed out by Hutchinson et al. (2021), whether these new relationships provide these entrepreneurs with a better quality of life and greater integration within their social environment.

\section{REFERENCES}

Akinyemi, E. O. (2016). Enterpreneurial empowerment of people with special needs in Ondo and Osun states, Nigeria. J. Arts Humanities 5, 26-38. doi: 10.18533/journal.v5i11.1013

Bagheri, A., and Abbariki, M. (2017). Competencies of disabled entrepreneurs in Iran: implications for learning and development. Disability Soc. 32, 69-92. doi: 10.1080/09687599.2016.1268524

Barba-Sánchez, V., and Molina-Ramírez, E. (2015). Efectos del apoyo emocional de las redes cercanas al emprendedor indígena sobre el éxito de la nueva empresa ecoturística en la mitad sur de México. Cuadernos de Turismo 36, 79-99. doi: 10.6018/turismo.36.230891

Barba-Sánchez, V., Ortíz-García, P., and Olaz-Capitán, A. (2019). Entrepreneurship and disability: methodological aspects and measurement instrument. $J$. Entrepreneurship Educ. 22, 1-6.

Barba-Sánchez, V., Salinero, Y., and Jiménez-Estévez, P. (2021). Monetising the social value of inclusive entrepreneurship: The case of the Abono Café social economy Enterprise. CIRIEC-España, Revista de Economía Pública, Social y Cooperativa 101, 115-141. doi: 10.7203/CIRIEC-E.101. 18158

Beisland, L. A., Mersland, R., and Zamore, S. (2016). Motivations for business start-up: are there any differences Between disabled and non-disabled microfinance clients? J. Inter. Dev. 28, 147-149. doi: 10.1002/jid.3196

Bengisu, M., and Balta, S. (2011). Employment of the workforce with disabilities in the hospitality industry. J. Sustainable Tourism 19, 35-57. doi: 10.1080/09669582.2010.499172

Borgatti, S., Mehra, A., Brass, D. J., and Labianca, G. (2009). Network analysis in the social sciences. Science 323, 892-895. doi: 10.1126/ science. 1165821

Bruce, D., and Schuetze, H. J. (2004). The labor market consequences of experience in self-employment. Labour Econ. 11, 575-598. doi: 10.1016/j. labeco.2003.10.002

Calderón-Milán, M. J., Calderón-Milán, B., and Barba-Sánchez, V. (2020). Labour inclusion of people with disabilities: what role do the social and solidarity economy entities play? Sustainability 12:1079. doi: 10.3390/su12031079

Caldwell, K., Harris, S. P., and Renko, M. (2020). Inclusive management for social entrepreneurs with intellectual disabilities: "how they act". J. Appl. Res. Intellectual Disabl. 33, 204-218. doi: 10.1111/jar.12662

\section{DATA AVAILABILITY STATEMENT}

The original contributions presented in the study are included in the article/supplementary material, further inquiries can be directed to the corresponding author.

\section{AUTHOR CONTRIBUTIONS}

VB-S, PJ-E, and YS have made the theoretical review and empirical study. EG has developed the interviews. All authors contributed to the article and approved the submitted version.

\section{FUNDING}

This work was supported by the Faculty of Legal and Social Science, University of Castilla-La Mancha, 45071 Toledo, Spain.

\section{ACKNOWLEDGMENTS}

Our thanks to CECAP for its help in obtaining the data of this study.

Conroy, J. W., Ferris, C. S., and Irvine, R. (2010). Microenterprise options for people with intellectual and developmental disabilities: An outcome evaluation. J. Policy Practice Intellectual Disabilities 7, 269-277. doi: 10.1111/j.1741-1130. 2010.00276.x

Darcy, S., Collins, J., and Stronach, M. (2020). Australia’s Disability Entrepreneurial Ecosystem: Experiences of People with Disability with Microenterprises, SelfEmployment and Entrepreneurship. Sydney: University of Technology Sydney.

Dhar, S., and Farzana, T. (2017). Entrepreneurs with disabilities in Bangladesh: an exploratory study on their entrepreneurial motivation and challenges. Eur. J. Bus. Manag. 9, 103-114.

Doyel, A. W. (2002). A realistic perspective of risk in self-employment for people with disabilities. J. vocational rehab. 17, 115-124.

Győri, Z., Svastics, C., and Csillag, S. (2019). "Push and pull motivations of entrepreneurs with disabilities in Hungary." In 7th International OFEL Conference on Governance, Management and Entrepreneurship: Embracing Diversity in Organisations; April 5-6, 2019; Dubrovnik, Croatia (Zagreb: Governance Research and Development Centre), 351-366.

Halabisky, D. (2014). Entrepreneurial Activities in Europe-Entrepreneurship for People with Disabilities. Surrey, UK: OECD Publishing.

Hashim, J., and Wok, S. (2014). Predictors to employees with disabilities' organisational behaviour and involvement in employment. Equality, Diversity Inclusion Inter. J. 33, 193-209. doi: 10.1108/EDI-03-2012-0018

Hutchinson, C., Lay, K., Alexander, J., and Ratcliffe, J. (2021). People with intellectual disabilities as business owners: A systematic review of peerreviewed literature. J. Appl. Res. Intel. Disabl. 34, 459-470. doi: 10.1111/ jar.12836

INE. (2018). El Empleo de las Personas con Discapacidad, 2017. Available at: https://www.ine.es/prensa/epd_2017.pdf

INE (2020). El Empleo de las Personas con Discapacidad (EPD). Notas de Prensa, Instituto Nacional de Estadística.

Keyes, C. (1998). Social well-being. Soc. Psychol. Q. 61, 121-140. doi: $10.2307 / 2787065$

Lancioni, G., Singh, N. N., O’Reilly, M. F. O., Sigafoos, J., Alberti, G., Zimbaro, C., et al. (2017). Using smartphones to help people with intellectual and sensory disabilities perform daily activities. Front. Public Health 5:282. doi: 10.3389/ fpubh.2017.00282

Larrinaga, O. V., and Rodríguez, J. L. (2010). El estudio de casos como metodología de investigación científica en dirección y economía de la empresa. 
Una aplicación a la internacionalización. Investigaciones Europeas de Dirección y Economía de la Empresa 16, 31-52. doi: 10.1016/S1135-2523(12)60033-1

Larsson, S. (2020). Disability management and entrepreneurship: results from a Nationwide study in Sweden. Inter. J. Disab. Manag. Res. 1, 159-168. doi: 10.1375/jdmr.1.1.159

Lee, R. P. L., Ruan, D., and Lai, G. (2005). Social structure and support networks in Bijing and Hong Kong. Soc. Networks 27, 249-274. doi: 10.1016/j. socnet.2005.04.001

Manzanera-Román, S., and Brändle, G. (2019). The type of disability as a differential factor in ntrepreneurship. J. Entrepreneurship Educ. 22, 1528-2651.

Maritz, A., and Laferriere, R. (2016). Entrepreneurship and self-employment for people with disabilities. Aus. J. Career Dev. 25, 45-54. doi: 10.1177/1038416216658044

Meager, N., and Higgins, T. (2011). Disability and skills in a changing economy. UK Commission for Employment and Skills, Briefing Paper Series. Available at: https://www.employment-studies.co.uk/resource/disability-and-skills-changingeconomy (Accessed May 2021).

Muñoz, R. M., Salinero, Y., Peña, I., de Pablo, S., and David, J. (2019). Entrepreneurship education and disability: An experience at a Spanish university. Administrative Sci. 9:34. doi: 10.3390/admsci9020034

O'Neil, I., Ucbasaran, D., and York, J. G. (2020). The evolution of founder identity as an authenticity work process. J. Bus. Venturing:106031. doi: 10.1016/j.jbeusvent.2020.106031 (in press).

ODISMET. (2018). Observatory on disability and labor market in Spain. Available at: http://www.odismet.es/

Ortíz-García, P., and Olaz-Capitán, A. (2021). Entrepreneurship for people with disabilities. From skills to social value. Fronti. Psychol. 12:699833. doi: 10.3389/ fpsyg.2021.699833

Pagán, R. (2009). Self-employment among people with disabilities: evidence for Europe. Disability Soc. 24, 217-229. doi: 10.1080/09687590802652504

Renko, M., Parker Harris, S., and Caldwell, K. (2015). Entrepreneurial entry by people with disabilities. Inter. Small Bus. J. 34, 1-24. doi: 10.1177/0266242615579112

Rutte, R., Westlund, H., and Boekema, F. (2010). The spatial dimension of social capital. Eur. Plan. Stud. 18, 863-871. doi: 10.1080/09654311003701381

Scott, J. (1991). Social Network Analysis. A Handbook. London, Sage Publications.
Seelman, K. D. (2008). Converging, pervasive technologies: chronic and emerging issues and policy adequacy. Assist. Technol. 20, 126-138. doi: 10.1080/10400435.2008.10131940

Thoresen, S. H., Thomson, A., Jackson, R., and Cocks, E. (2018). Meaningful social and economic inclusion through small business enterprise models of employment for adults with intellectual disability. J. Vocational Rehab. 49, 161-172. doi: 10.3233/JVR-180962

Tirado-Valencia, P., Ayuso, S., and Fernández-Rodríguez, V. (2021). Accounting for emotional value: A review in disability organizations. Front. Psychol. 12:741897. doi: 10.3389/fpsyg.2021.741897

van Asselt-Goverts, A. E., Embregts, P. J. C. M., Hendriks, A. H. C., and Frielink, N. (2014). Experiences of support staff with expanding and strengthening social networks of people with mild intellectual disabilities. J. Community Appl. Soc. Psychol. 24, 111-124. doi: 10.1002/casp.2156

Villarreal, L. O., and Landeta, R. J. (2010). El estudio de casos como metodología de investigación científica en dirección y economía de la empresa: una aplicación a la internacionalización. Investigaciones Europeas de Dirección y Economía de la Empresa 16, 31-52.

Yin, R. K. (1989). Case Study Research. Design and Methods, Applied Social Research Methods Series. London, England: Sage Publications.

Conflict of Interest: The authors declare that the research was conducted in the absence of any commercial or financial relationships that could be construed as a potential conflict of interest.

Publisher's Note: All claims expressed in this article are solely those of the authors and do not necessarily represent those of their affiliated organizations, or those of the publisher, the editors and the reviewers. Any product that may be evaluated in this article, or claim that may be made by its manufacturer, is not guaranteed or endorsed by the publisher.

Copyright (C) 2021 Barba-Sánchez, Salinero, Jiménez-Estevez and Galindo. This is an open-access article distributed under the terms of the Creative Commons Attribution License (CC BY). The use, distribution or reproduction in other forums is permitted, provided the original author(s) and the copyright owner(s) are credited and that the original publication in this journal is cited, in accordance with accepted academic practice. No use, distribution or reproduction is permitted which does not comply with these terms. 